Jurnal Inkofar * Volume 1 No. 2, Desember 2017 * ISSN: 2615-3645 (Print) / 2581-2920 (Online)

Tersedia secara online di: http://www.politeknikmeta.ac.id/meta/ojs/

\title{
STRATEGI TIDUR SEHAT SEBAGAI UPAYA PENCEGAHAN TERHADAP HIPERTENSI DINI
}

\author{
Nindya Sekar Mayuri ${ }^{1}$, Sofidita Ghifrani ${ }^{2}$, Haula Nanda Ardinia ${ }^{3}$, Rosiana Dwy Setyaningsih ${ }^{4}$ \\ Program Studi Farmasi Politeknik META Industri Cikarang, Kab. Bekasi, Indonesia ${ }^{1,2,3,4}$ \\ nindya@politeknikmeta.ac.id
}

\begin{abstract}
Health problems such as Infectious Desease and Non Communicable Disease (NCDs), need to be a serious concern, especially in Indonesia. Currently, NCDs like cancer, Diabetes Mellitus (DM), hypertension, coronary heart disease, and stroke become serious problems that need to be wary of. Prevalence of hypertension disease in Indonesia has increased which is happen not only in elderly but also increased in children and adolescents. This early hypertension can occur due to poor lifestyle, such as poor sleep quality. Therefore, it is necessary to study the strategy of healthy sleep to prevent hypertension in adolescene caused by poor sleep quality. The methods using qualitative methods with data sources from journals which related to concepts of hypertension, physiological sleep, sleep patterns, and blood pressure. Based on literature study, it can be concluded that to prevent early hypertension is by doing healthy sleep, there are: have enough sleep time, about 6-7 hours per day, take a short nap in heavy activities and turn off the lights during sleep.
\end{abstract}

Keywords: blood pressure, early hypertension, NCDs, sleep.

\begin{abstract}
ABSTRAK
Negara dengan jumlah penduduk yang padat harus memiliki perhatian yang lebih terhadap kesehatan penduduknya. Masalah kesehatan seperti Penyakit Menular (PM) dan Penyakit Tidak Menular (PTM), perlu menjadi perhatian serius, khususnya Indonesia. Saat ini penyakit yang termasuk dalam PTM seperti kanker, Diabetes Melitus (DM), hipertensi, jantung coroner, dan stroke menjadi masalah serius yang perlu diwaspadai. Hipertensi merupakan penyakit yang pravelensinya di Indonesia terus mengalami peningkatan. Hipertensi ini tidak hanya terjadi pada lansia tetap saat ini prevelensinya meningkat pada usia anak anak dan remaja. Hipertensi dini ini dapat terjadi karena pola gaya hidup yang buruk, seperti kualitas tidur yang buruk. Oleh karena itu, diperlukan studi tentang strategi tidur sehat agar pola tidur yang tidak berkualitas pada usia remaja saat ini tidak berefek pada hipertensi pada jangka panjang. Metode yang digunakan dalam perolehan data adalah dengan metode kualitatif dengan sumber data dari jurnal yang berhubungan dengan konsep-konsep yang berhubungan dengan hipertensi, fisiologis tidur, pola tidur, tekanan darah. Berdasarkan studi pustaka, dapat disimpulkan bahwa upaya yang dapat dilakukan untuk melakukan pencegahan terhadap hipertensi dini adalah dengan menerapkan tidur sehat, yaitu: melakukan tidur yang cukup, sekitar 6-7 jam per hari, melakukan tidur siang singkat ditengah aktivitas berat, pada jam istirahat, dan mematikan lampu saat tidur.
\end{abstract}

Kata Kunci : hipertensi dini, PTM, tekanan darah, tidur.

\section{PENDAHULUAN}

Negara dengan jumlah penduduk yang padat harus memiliki perhatian yang lebih terhadap kesehatan penduduknya. Masalah kesehatan seperti Penyakit Menular (PM) dan Penyakit Tidak Menular (PTM), perlu menjadi perhatian serius, khususnya Indonesia. Indonesia merupakan Negara berkembang dengan jumlah penduduk usia produktif (15-64 tahun) sebesar 67\% dari total keseluruhan (Pusdatin Kemenkes 2016). Pada usia-usia tersebut, penduduk rentan terkena berbagai macam penyakit yang dapat mengganggu aktivitas sehari-hari. Saat ini penyakit yang termasuk dalam PTM seperti kanker, Diabetes Melitus (DM), hipertensi, jantung coroner, dan stroke menjadi masalah serius yang perlu diwaspadai (Riskesdas, 2013).

Hipertensi merupakan penyakit yang pravelensinya di Indonesia terus mengalami peningkatan. Data Kementerian Kesehatan menyatakan bahwa sebanyak 31\% penduduk Indonesia menderita hipertensi atau tekanan darah tinggi, dengan 1 dari 3 orang menderita penyakit tersebut (Movementi, 2013). Hipertensi merupakan penyakit yang disebabkan oleh tekanan darah di pembuluh darah yang 
meningkat secara kronis. Menurut Dr. Sundari, A. Per. Pen., M.Kes bahwa hipertensi esensial dipengaruhi oleh faktor usia dan keturunan. Semakin tua usia (lansia), mempunyai resiko tiga kali lipat mengalami hipertensi dari usia dewasa. Usia lebih dari 40 tahun beresiko terkena penyakit hipertensi dan untuk yang memiliki keturunan hipertensi maka kemungkinan 25\% akan mengidap penyakit ini. Selain itu hipertensi esensial juga dipengaruhi faktor lain seperti, lingkungan, perilaku dan faktor predisposing (Angga, 2012). Hal ini juga sesuai dengan yang diungkapkan oleh Bell dkk. (2015) bahwa hipertensi dapat disebabkan oleh pola hidup yang tidak sehat, seperti merokok, makanan banyak mengandung garam, kurangnya istirahat, stres, penggunaan alkohol berlebihan, serta kurangnya aktivitas fisik.

Saat ini, penyakit hipertensi tidak hanya terjadi pada usia diatas 40 tahun saja, usia remaja bahkan anak-anak pun dapat terkena penyakit mematikan ini. Tingginya tekanan darah dapat teridentifikasi pada usia anak anak dan remaja, yang prevelensinya terus mengalami peningkatan. Sama halnya dengan hipertensi yang terjadi pada orang dewasa, hipertensi pada anak-anak dan remaja juga dapat disebabkan oleh obesitas dan faktor gaya hidup. Anak-anak yang mengalami hipertensi dapat menyebabkan kerusakan organ, seperti hipertropi ventrikel kiri, penebalan dinding carotid, perubahan pembuluh darah retina, serta perubahan dari aspek kognitif. Tingginya tekanan darah pada anak-anak dan remaja dapat beakibat pada kesehatan secara keseluruhan pada jangka panjang (Falkner, 2009).

Salah satu gaya hidup tidak sehat yang dapat menyebabkan hipertensi adalah kurangnya istirahat. Tidur merupakan respon alamiah tubuh agar tubuh dapat beristirahat dan merupakan suatu kebutuhan. Namun, saat ini tidur bukanlah prioritas utama ketika seseorang sudah mengalami kelelahan akibat aktivitas yang tinggi. Rata-rata orang menggunakan gadget untuk melepas penat, seperti bermain game online atau bahkan membuka berbagai media sosial seperti Whatsapp, Facebook, dan Instagram yang menyebabkan berkurangnya jam tidur seseorang. Pada usia remaja, yang rata-rata pada usia tersebut merupakan usia anak sekolah, dari Sekolah Menengah Atas sampai tingkat Perguruan Tinggi, tuntutan untuk dapat menyelesaikan tugas-tugas sekolah dan kuliah menjadi prioritas utama. Oleh karena itu, akhirnya para siswa dan mahasiswa mengurangi durasi jam tidur normal. Durasi tidur yang tidak mencukupi atau dalam kata lain begadang dapat berakibat buruk pada tekanan darah seseorang, dan apabila terus dilakukan dapat mengalami hipertensi. Seperti penelitian yang dilakukan oleh $\mathrm{Au}$ dkk. (2014) bahwa pendeknya lama waktu tidur berhubungan dengan tingginya tekanan darah pada usia remaja dengan berat badan normal. Palagini dkk. (2013) mengungkapkan bahwa terjadi peningkatan prevelensi hipertensi yang berhubungan dengan peningkatan seseorang melakukan pengurangan durasi tidur akibat dari gaya hidup.

Berdasarkan penjelasan-penjelasan tersebut, dapat diketahui bahwa hipertensi tidak hanya terjadi pada usia lanjut (lansia), tetapi dapat terjadi sejak dini, yaitu pada usia remaja akibat kurangnya lamanya waktu tidur. Oleh karena itu, diperlukan strategi tidur sehat agar pola tidur yang tidak berkualitas pada usia remaja saat ini tidak berefek pada hipertensi pada jangka panjang.

\section{STUDI PUSTAKA}

\subsection{Hipertensi}

Hipertensi didefinisikan sebgai tekanan darah sistolik (TDS) mencapai lebih dari $140 \mathrm{mmHg}$ atau tekanan darah diastolik (TDD) lebih besar dari $90 \mathrm{mmHg}$. Hipertensi terjadi akibat peningkatan tonus otot polos vaskuler perifer, yang mengakibatkan peningkatan resistensi arterior dan penurunan kapasitas sistem vena. Pada sebagaian besar kasus, penyebab peningkatan tonus vaskuler tidak diketahui (Harvey dan Champe, 2016). Hipertensi dapat terjadi pada usia anak dan remaja, dengan pembagian kelompok terdapat pada Tabel 1.

Tabel 1. Klasifikasi Hipertensi

\begin{tabular}{|l|c|c|c|}
\hline \multicolumn{1}{|c|}{ Kategori } & $\begin{array}{c}\text { 16 tahun ke atas } \\
\text { SBP dan/atau DBP } \\
(\mathbf{m m H g}) *\end{array}$ & $\begin{array}{c}\text { Tekanan darah } \\
\text { sistol }(\mathbf{m m H g}) * *\end{array}$ & $\begin{array}{c}\text { Tekanan darah } \\
\text { diastol }(\mathbf{m m H g}) * *\end{array}$ \\
\hline Normal & $<130 / 85$ & $<120$ & $<80$ \\
\hline Normal-Tinggi & $130-139 / 85-89$ & - & - \\
\hline Pre-hipertensi & - & $120-139$ & $80-89$ \\
\hline Hipertensi & $\geq 140 / 90$ & - & - \\
\hline
\end{tabular}


Jurnal Inkofar * Volume 1 No. 2, Desember 2017 * ISSN: 2615-3645 (Print) / 2581-2920 (Online)

Tersedia secara online di: http://www.politeknikmeta.ac.id/meta/ojs/

\begin{tabular}{|l|c|c|c|}
\hline Hipertensi Stage 1 & $140-159 / 90-99$ & $140-159$ & $90-99$ \\
\hline Hipertensi Stage 2 & $160-179 / 100-109$ & 160 atau $>160$ & 100 atau $>100$ \\
\hline
\end{tabular}

Ket : * Lurbe dkk., 2016, ** JNC 7, 2004.

Hipertensi berdasarkan penyebabnya dibagi menjadi dua golongan, yaitu hipertensi primer/esensial dan hipertensi sekunder. Hipertensi primer adalah hipertensi yang belum diketahui penyebab pastinya, namun beberapa faktor yang diduga berperan adalah faktor usia, stress psikologis, dan hereditas. Hipertensi primer disebabkan oleh penyebab yang sudah jelas, seperti penyakit kelainan pembuluh darah ginjal, gangguan kelenjar tiroid (hipertiroid), dan penyakit kelenjar adrenal (hiperaldosteronisme). Sekitar 90\% penderita hipertensi tergolong hipertensi primer (LIPI, 2009)

\subsection{Tidur}

Tidur merupakan suatu kebutuhan yang merupakan bentuk perlindungan dari organisme untuk menghindari pengaruh yang merugikan tubuh karena kurang tidur. Efek terpenting yang mempengaruhi kulaitas tidur adalah penyingkatan waktu menidurkan, perpanjangan masa tidur dan pengurangan jumlah periode terbangun. Pusat tidur di otak (sumsum lanjutan) mengatur fungsi fisiologi ini yang sangat penting bagi kesehatan tubuh. Pada waktu tidur, aktivitas saraf simpatis meningkat, dengan efek penyempitan pupil (myosis), perlambatan pernapasan dan sirkulasi darah (bronchokontriksi dan menurunnya kegiatan jantung) serta stimulasi aktivitas saluran cerna dengan penguatan peristaltik dan sekresi getah lambung-usus. Singkatnya, proses-proses pengumpulan energi dan pemulihan tenaga dari organisme diperkuat.

Pada saat tidur, umumnya selama satu malam dapat dibedakan 4-5 siklus tidur dari kira-kira 1,5 jam. Setiap siklus terdiri dari dua stadium, yakni tidur non-REM dan tidur REM.

a) Tidur non-Rapid Eye Movement (REM), juga disebut Slow wave sleep (SWS) berdasarkan registrasi aktivitas listrik otak (EEG=Elektro-ence-falogram). Non-REM bercirikan denyut jantung, tekanan darah dan pernapasan yang teratur serta relaksasi otot tanpa gerakan otot muka atau mata. Slow wave sleep ini berlangsung lebih kurang 1 jam lamanya dan meliputi berturut-turut 4 fase, dimana fase 3 dan 4 merupakan bentuk tidur yang terdalam, dengan melepaskan hormone--hormon anabolik dan sitokin. Peristiwa ini penting untuk daya tahan tubuh, metabolisme dan reparasi alamaiah sel-sel tubuh. Berdasarkan hal ini SWS menjadi lebih panjang pada keadaan-keadaan yang membutuhkan pertumbuhan atau konservasi, misalnya pada kehamilan, pertumbuhan dan thyroto-xicosis. Fase ini disusul oleh stadium tidur REM (Tjay dan Raharja, 2015).

b) Tidur Rapid Eye Movement (REM) atau tidur paradoksal, dengan aktivitas EEG yang mirip dengan keadaan sadar dan aktif, bercirikan dengan gerakan mata cepat ke satu arah. Disamping itu, jantung, tekanan darah dan pernapasan turun-naik, aliran darah ke otak bertambah dan otot-otot sangat relaks. Selama tidur REM yang pada kedua siklus pertama berlangsung 5-15 menit lamanya, timbul banyak impian, sehingga disebut juga tidur mimpi. Berangsur-angsur mimpi ini menjadi lebih panjang, hingga pada siklus terakhir (pada pagi hari) dapat berlangusng rata-rata antara 20-30 menit lamanya (Tjay dan Raharja, 2015).

\subsection{Gangguan Tidur dan Akibat Fisiologis Terhadap Tubuh}

Gangguan tidur dapat terjadi karena banyak hal. Tidur dalam waktu yang rendah menyebabkan perubahan fisiologi yang abnormal, termasuk penurunan toleransi terhadap glukosa, peningkatan tekanan darah, aktivasinya sistem saraf simpatik, menurunnya kadar leptin, dan meningkatnya inflamasi (Gambar 1.). Namun, ini akan terjadi jika perilaku tidur tidak cukup dilakukan secara berkepanjangan. 


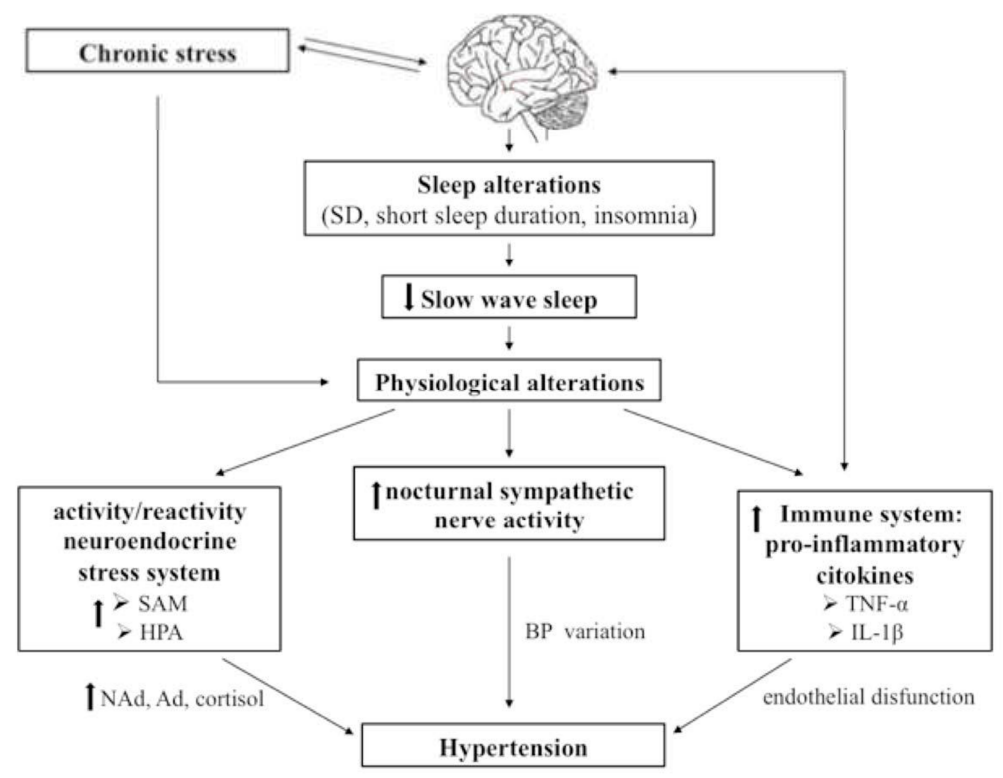

Gambar 1. Hubungan diantara perubahan jam tidur, stress, hypothalamic-pituitary-adrenal axis (HPA), sympathetic adrenal medullary axis (SAM), system saraf pusat simpatik, inflamasi dan hipertensi. SD: sleep deprivation (begadang); NAD: noradrenalin; Ad: adrenalin; BP: blood pressure (tekanan darah); TNF: tumor necrosis factor; IL: interleukin (Palagini dkk., 2013).

Beberapa respon fisiologis tubuh yang berpengaruh adalah :

1. Respon endokrin

Berdasarkan penelitian yang dilakukan oleh Spiegel 1999 bahwa dibandingkan dengan gangguan tidur (4 jam per malam selama 6 malam) dan tidur panjang (12 jam per malam selama 6 malam) pada remaja yang sehat, menyebabkan peningkatan kadar kortisol pada malam hari, peningkatan aktivitas simpatik, penurunan aktifitas thyrotropin, dan penuruanan toleransi glukosa dibandingkan tidur yang panjang. Selain itu hormon leptin yang dihasilkan pada tidur yang hanya sebentar dapat menyebabkan penururnan, sehingga orang akan terus merasa lapar dan menyebabkan obesitas.

2. Respon Imun

Berdasarkan studi literatur, sedikitnya jam tidur menyebabkan produksi antibodi menurun. Dalam penelitian lain menyebutkan bahwa, penurunan antibodi $50 \%$ per hari setelah divaksinansi untuk influenza. Studi lain menunjukkan bahwa remaja yang tidur hanya kurang dari 6 jam per hari, setelah 24 jam profile IL-6 sekretori meningkat dan TNF alpha juga meningkat pada laki-laki. Baik IL-6 ataupun TNF-alpha adalah markers dari sistem peradangan yang memicu resistensi terhadap insulin, penyakit kardiovaskular, dan osteoporosis.

3. Sistem Kardiovaskular

Berdasarkan penelitian yang ada bahwa resiko jantung koroner pada wanita yang tidurnya kurang dari 7 jam menjadi lebih tinggi, studi lain menyebutkan yang tidurnya kurang dari 5 jam per hari. Kemungkinan C-Reactive Protein (CRP) adalah marker peradangan yang merupakan predictor positif untuk peningkatan resiko penyakit kardiovaskular (Banks dan Dingers, 2007).

\subsection{Penanggulangan Hipertensi Masa Kini}

Saat ini penanggulangan hipertensi dapat dilakukan secara farmakologis dan non farmakologis. Menurut Lurbe dkk. (2016). Secara non-farmakologi dilakukan jika hipertensi tersebut tidak diikuti dengan gejala kerusakan organ dan diabetes. Sehingga dapat dilakukan perubahan gaya hidup, melalui pengontrolan Indeks Massa Tubuh (IMT), melakukan diet khususnya terhadap garam, serta melakukan berbagai aktivitas fisik. Tidur bukanlah menjadi faktor penting dalam pencegahan hipertensi, padahal penelitian-penelitian sudah menyatakan bahwa terdapat hubungan antara kualitas tidur dengan hipertensi, sehingga saat ini faktor tidur belum banyak 
mendapatkan perhatian dari semua orang. Jika hipertensi sudah diikuti dengan kerusakan organ dan penyakit-penyakit lainnya seperti diabetes, maka secara farmakologis pengobatan dapat dilakukan. Penggunaan obat seperti yang termasuk dalam kelas diuretic, beta blockers, calcium channel blocker, ACE inhibitors, ARBs, dan vasodilator dapat dikombinasikan dan diberikan pada anak-anak atau remaja yang terkena hipertensi (Lurbe dkk., 2016).

\section{METODE PENELITIAN}

Penelitian ini merupakan penelitian kualitatif. Metodologi yang digunakan dalam ruang lingkup penelitian kualitatif ini adalah melalui studi teks dan dokumentasi. Penelitian ini menitikberatkan pada analisis atau interpretasi bahan tertulis berdasarkan konteksnya. Data diperoleh melalui studi literatur terhadap konsep-konsep yang berhubungan dengan hipertensi, fisiologis tidur, pola tidur, dan tekanan darah. Sumber literatur yang digunakan merupakan jurnal ilmiah nasional maupun internasional serta data-data statistika yang berhubungan dengan kesehatan.

\section{ANALISIS DAN SINTESIS}

Tidur sehat yang dimaksud ini adalah tidur yang dilakukan seseorang yang tidak mengakibatkan gangguan kesehatan, justru akan membuat seseorang tersebut dapat merasakan manfaat yang positif bagi kesehatannya. Beberapa orang tidak mengetahui bagaimana cara tidur yang benar. Tidur sehat dapat dilakukan dengan cara melakukan keadaan tidur yang berkualitas. Tidur yang berkualitas adalah suatu keadaan dimana tidur yang dijalani oleh seseorang menghasilkan kesegaran dan kebugaran ketika terbangun di pagi hari (Nashory dan Diana, 2005). Berdasarkan penelitian yang dilakukan oleh Rinda dkk. (2017) pada anak remaja bahwa semakin baik kualitas tidur maka semakin normal tekanan darah dan semakin buruk kualitas tidur maka semakin tinggi tekanan darah. Beberapa faktor yang dapat mempengaruhi tidur yang berkualitas adalah :

\subsection{Lamanya waktu tidur}

Lamanya waktu tidur seseorang bergantung pada usia, semakin dewasa, lamanya waktu tidur semakin berkurang (Tabel 2).

Tabel 2. Pengaruh umur terhadap jumlah kebutuhan tidur

\begin{tabular}{|l|l|l|}
\hline \multicolumn{1}{|c|}{ Umur } & Tingkat Perkembangan & Jumlah Kebutuhan Tidur \\
\hline $0-8$ bulan & Bayi baru lahir & $14-18$ jam / hari \\
\hline $1-8$ bulan & Masa bayi & $12-14$ jam / hari \\
\hline 18 bulan-3 tahun & Masa anak & $11-12 \mathrm{jam} /$ hari \\
\hline 3-6 tahun & Masa prasekolah & $11 \mathrm{jam} /$ hari \\
\hline 6-12 tahun & Masa sekolah & $10 \mathrm{jam} /$ hari \\
\hline 12-18 tahun & Masa Remaja & $8,5 \mathrm{jam} /$ hari \\
\hline 18-40 tahun & Masa Dewasa & $7-8 \mathrm{jam} /$ hari \\
\hline $40-60$ tahun & Masa muda paruh baya & $7 \mathrm{jam} /$ hari \\
\hline 60 tahun ke atas & Masa dewasa tua & $6 \mathrm{jam} /$ hari \\
\hline
\end{tabular}

Ketika seseorang tidur dalam waktu yang tidak mencukupi dengan jumlah kebutuhan yang seharusnya maka tubuh akan merespon perubahan tersebut. Perubahan yang terjadi akan menyebabkan gangguan pada kesehatan seperti menurunnya respon imun, peningkatan berat badan akibat kurangnya hormon leptin yang dihasilkan, serta terjadi peningkatan resiko terkena penyakit jantung koroner. Beberapa penelitian yang telah dilakukan terhadap pengaruh kurangnya waktu tidur dengan tekanan darah menunjukkan bahwa, tidur yang tidak mencukupi dan dilakukan secara berkelanjutan pada seseorang akan menyebabkan peningkatan tekanan darah dan pada akhirnya menimbulkan penyakit hipertensi. Menurut Pallagini dkk. (2013), begadang akan menginduksi peningkatan tekanan darah baik untuk yang memiliki tekanan darah normal, prehipertensi, dan hipertensi, baik yang sudah dewasa ataupun remaja, laki laki maupun perempuan. Sedikitnya waktu tidur (kurang dari 5-6 jam) akan menyebabkan berkembangnya penyakit hipertensi. Resiko tersebut semakin tinggi jika terjadi pada seseorang dengan berat badan berlebih atau obesitas. Pada penderita obesitas di kalangan remaja, 
Jurnal Inkofar* Volume 1 No. 2, Desember 2017 * ISSN: 2615-3645 (Print) / 2581-2920 (Online)

Tersedia secara online di: http://www.politeknikmeta.ac.id/meta/ojs/

rendahnya tahapan tidur mendalam, REM dan SWS menyebabkan tingginya tekanan darah pagi hari (Hannon dkk., 2014).

\subsection{Pengaruh Tidur Siang Terhadap Kualitas Tidur di Malam Hari}

Berdasarkan hasil penelitian yang ada, bahwa tidur siang dapat memberikan efek yang positif terhadap tubuh. Orang yang melakukan tidur siang di tengah aktivitas padat memiliki tekanan darah sistol dan diastole yang lebih rendah, beban tekanan yang lebih rendah dibandingkan dengan yang tidak melakukan tidur siang (Gomes dkk., 2000). Tetapi pengaturan terhadap tidur siang juga perlu dilakukan pengontrolan, karena tidur siang yang terlalu lama akan menyebabkan kerusakan fungsi terjaga (Potter dan Perry dalam Indrawati, 2012).

\subsection{Pengaruh Cahaya Terhadap Kondisi Tidur}

Cahaya dapat berpengaruh terhadap kualitas tidur seseorang. Berdasarkan penelitian yang dilakukan oleh Burgess dan Molina tahun 2014 bahwa seseorang yang menghidupkan lampu saat sebelum tertidur akan menyebabkan gangguan pada circardian time. Hal ini berhubungan dengan produksi melatonin. Produksi melatonin akan menurun jika terpapar oleh cahaya. Melatonin berperan penting dalam mekanisme tidur. Penelitian yang dilakukan oleh Rusmiyati, dkk. (2015) menyimpulkan bahwa lampu yang mati pada saat tidur membuat kinerja hormon melantonin maksimal sehingga tubuh dan otak beristirahat secara penuh sehingga kulitas tidur menjadi lebih baik.

\section{KESIMPULAN}

Berdasarkan analsis terhadap strategi penanggulangan hipertensi melalui gaya hidup, dapat disimpulkan bahwa strategi untuk pencegahan hipertensi dini adalah dengan melakukan pola tidur sehat, yaitu :

1. Melakukan tidur yang cukup, sekitar 6-7 jam per hari.

2. Melakukan tidur siang singkat ditengah aktivitas berat, pada jam istirahat.

3. Mematikan lampu saat tidur.

\section{DAFTAR PUSTAKA}

Angga. 2012. Disertasi Doktor: Dr. Sundari, A. Per. Pen., M. Kes., diakses pada halaman: http://www.fk.ub.ac.id/disertasi-doktor-dr-sundari-a-per-pen-m-kes/ [26 November 2017]

Au, C.T., Phil,M., Ho,C.K.W., Hugh, Wing, Y.K., Lam, S.L., Li, A.M, 2014, Acute and Chronic Effects of Sleep Duration on Blood Pressure. Pediatrics, 133: e64-e72.

Banks, S., Dingers, D.F, 2007, Behavioral and Physiological Consequences of Sleep Restriction, Journal of Clinical Sleep Medicine, 3(5):519-528.

Bell,K., Twigs,J., Olin,B.R, 2015, Hypertension the silent killer : Update JNC 8 Guidelines recommendations, Albama Pharmacy Ascociation.

Burgess, H.J., Molina, T.A, 2014, Home Lighting Before Usual Bedtime Impacts Circadian Timing:A Field Study, Photochem Photobiol, 90(3): 723-726.

Falkner, B, 2009, Hypertension in children and adolescents: epidemiology and natural history, Pediatr Nephrol, 25: 1219-1224.

Gomes, M.A.M., Pierin,A.M.G., Mion,D, 2000, The Effect Of Siesta In Parameters Of Cadiac Structure And In Interpretation Of Ambulatory Arterial Blood Pressure Monitoring, Aq Bras Cardiol, 74(4) : 314-318

Hannon, T.S., Tu,W., Watson,S.E., Jalou,H., Chakravorty, S., Arslanian, S, 2014, Morning Blood Pressure is Associated witth Sleep Quality in Obese Adolescents . J. Pediatr, 164(2) : 313317.

Harvey, R.A \& Champe, P.C, 2016, Farmakologi Ulasan Bergambar, EGC : Jakarta, hal. 253-254.

Indarwati, N, 2012, Perbandingan Kualitas Tidur Mahasiswa Yang Mengikuti Ukm Dan Tidak Mengikuti Ukm Pada Mahasiswa Regular FIK UI. Skripsi Fakultas Ilmu Keperawatan. Universitas Indonesia, Depok.

JNC (Joint National Comitte), 2004, Prevention, Detection, Evaluation, and Treatment of High Blood Pressure, diakses pada halaman: www.nhlbi.nih.gov [18 November 2017]

Kemenkes RI, 2016, Istirahat cukup. diakses pada halaman: www.promkes.depkes.go.id [22 November 2017] 
LIPI, 2009, Hipertensi, diakses pada halaman: www.bit.lipi.go.id/ [18 November 2017]

Lurbe, E., Agabiti-Rosei,E., Cruickshank,J.K., Dominiczak,A., Erdiner,S., Hirth,A., Invitti,C., Litwin,M., Mancia,G., Palk,D., Raschen,W., Redon,J., Schaefer,F., Seeman,T., Sinha,M., Stabouli,S., Webb,N.J., Wu, E., dan Zanchetti,A, 2016, 2016 European Society Of hypertension Guidelines Forthemanagement Of High Blood Pressure In Childrenand Adolescents, Journal of Hypertension, 34(1): 1-34.

Movementi, S, 2013, 31 Persen Penduduk Indonesia Mengidap Hipertensi., diakses pada halaman: https://nasional.tempo.co/read/471229/31-persen-penduduk-indonesia-mengidap-hipertensi [22 November 2017]

Nashori,F., Diana,R., 2005, Perbedaan Kualitas Tidur Dan Kualitas Mimpi Antara Mahasiswa LakiLaki Dan Mahasiswa Perempuan, Humanitas Indonesian Psychological Journal, 2(2): 77 88.

Palagini,L., Bruno R.M., Gemignani, A., Baglioni,C., Ghiadoni,L., Riemann, D, 2013, Sleep Loss and Hypertension: A Systematic Review, Current Pharmaceutical Design, $19: 1-11$.

Pusdatin Kemenkes RI 2016. Hipertensi. diakses pada halaman: www.depkes.go.id [18 November 2017]jnc

Riskesdas, 2013. Riset Kesehatan Dasar 2013, diakses pada halaman: www.depkes.go.id [18 November 2017]

Rusmiyati, R.S., Tafwidhah,Y., Irsan,A, 2015, Penggaruh Penggunan Lampu Pada Saat Tidur Terhadap Kualitas Tidur Remaja Di Madrasah Aliyah Negeri 2 Pontianak. Skripsi. Prodi Keperawatan. Universitas Tanjungpura, Pontianak.

Tjay T.H, Rahardja, K. 2015, Obat-obat penting, Elex Media Komputindo: Jakarta, hal. 387-388. 